\title{
Oral Presentation to Improve the Students' Speaking Skill of the Seventh Grade Students at SMPN 35 Surabaya
}

\author{
Laely Vitriyati \\ SMPN 35 Surabaya, Email: lelyvitri70@gmail.com
}

\begin{abstract}
The aim of the study was to improve the students' ability in speaking skill by applying Classroom Action Research (CAR) using a collaborative design. The procedures of the study consist of five steps, namely: preliminary study, planning, implementing the plan, observing the action, and reflecting on the action. The study was conducted in two cycles. The study was conducted at SMPN 35 Surabaya. It was applied in the first semester of the academic year 2020/2021. The subjects of the study were the ninth-grade students comprising 41 students. The data of the study were obtained from the following research instrument: observation and test. The improvement was indicated by the increasing of the students' mean scores of speaking skill test administered at the end of students' means score in preliminary study was indicated by the increasing of the students' means score in preliminary study was 6.95 in the first cycle and 7.21 in the second cycle. Meanwhile, the percentage of increasing was from $46 \%$ (first cycle) to $75 \%$ (second cycle).
\end{abstract}

Keywords: speaking skill, classroom action research, oral presentation

\section{INTRODUCTION}

English is extremely important for anyone who want to obtain access to the global communication system, in which people use both spoken and written English language in order to communicate effectively. When English is taught in Indonesian schools, it is considered a foreign language and is taught from the kindergarten level up to the university level. The teaching and learning of English encompass the four language skills (listening, speaking, reading, and writing), as well as the language components (structure, vocabulary, and pronunciation), all of which are taught in a way that they operate together harmoniously. Speaking as a mode of oral communication in the information age must be taught and promoted by every English-language teacher in Indonesia in order for the country to progress. Being able to communicate well in English is considered to be one of the most important goals for English learners in terms of personal happiness, but it is also a desirable qualification for pursuing other hobbies or pursuing a profession. When studying a second or foreign language according to Nunan (1991, p. 39), "mastering the skill of speaking is considered to be the single most 
important part of learning a second or foreign language, and success is judged in terms of the capacity to carry on a conversation in the language."

According to the teacher's observations as an English teacher, the problem is caused by a variety of factors. Many students claim that they are inactive and hesitant to speak English because they have neither an idea to communicate nor confidence in their ability to understand the issues being discussed in class. When they are faced with a circumstance in which they are expected to communicate orally in English, they are more likely to be apprehensive. Others claim that they are terrified of making mistakes in both grammar and pronunciation because they are afraid that their friends will laugh at them, which would make them feel embarrassed. Their behavior makes them appear foolish in front of their peers and the teacher. Furthermore, some people do not believe that learning English is necessary for them to be successful in their future lives. They just believe that because English is not their native language, they have no reason to be concerned about learning it.

The problem of learning-teaching speaking becomes more complicated due to the results of the technique of teaching speaking has been done so far. Teachers use conventional and monotonous technique of teaching. The teaching of speaking has been done by giving the students some sample dialogues and asking them to perform the dialogues in front of class. This way of teaching does not provide the students with a real and natural speaking situation in which they have to interact with other people in the real world. Being conditioned by the culture of this way of teaching, the students become passive and accustomed to being spoon-fed. They like to be told what to do and they do only what is clearly essential to get a good grade. This makes unmotivated students more frustrated because they find nothing interesting nor challenging in the process of learning which they are involved in. Attitudes and behaviors like these make learning more difficult and must be changed.

From the statements above, we can understand that the basic competence of speaking skills is to express meaning in transactional and interpersonal conversation shortly and simply to make an interaction with the nearest surroundings. So, it is suitable that the researcher integrates those others based on the concepts of oral presentation or oral reports they have learned. Based on the background above, this Classroom Action Research is conducted to develop the technique or strategy of teaching speaking through 
Oral Presentation which is believed to solve the students' speaking problems and at last to improve the students' speaking skill. Based on the research background above, the statement of the problem is formulated: "How does Oral Presentation improve the speaking ability of the ninth-grade students at SMPN 35 Surabaya?"

\section{REVIEW OF THE RELATED LITERATURE}

\section{Speaking}

In their book "Language Arts," Tompkins and Hoskisson (1991) describe ass talk as the primary expressive language mode, which they refer to as "ass talk." In fact, both children and adults use it more frequently than writing, and youngsters learn to talk before they learn to read and write themselves. Moreover, they characterized speaking as a way of communication that has been developed by all people all over the globe. Because of this, English plays a crucial part in everyday life. For their part, Richards and Renandya $(2002,2002)$ asserted that speaking is the ability to express particular objectives, and that each purpose required a distinct set of skills. Aside from that, speaking means being able to communicate in a foreign language or dialect. Speaking ability is defined as the ability to articulate oneself in a real-life setting, or the ability to report acts as a circumstance in precise words, or the ability to converse or to express a sequence of ideas effectively in a conversation or a presentation. Student's abilities in English include: listening, speaking, reading, and writing. Speaking is a highly significant ability for students who learn English. There are numerous spellings for the same term in different dialects of English. Oral instruction takes precedence over the presentation of materials on paper.

\section{Classroom Speaking Activities}

Many of the classroom speaking activities that are now in use are at or near the communicative end of the communication continuum, which is a good thing for students (Harmer, 2007). Several commonly-used categories of speaking activity, according to him, will be discussed first, before moving on to particular speaking examples in the following section. Classroom speaking activities can be divided into categories based on the student's views or opinions:

\section{Acting from a script}

Teachers can encourage our students to act out scenes from plays and/or their course book, with the outcomes sometimes being recorded on video by the teacher. 
Students would frequently play out dialogues that they have written themselves in their classrooms. There are two types of actions that can be performed using this script. They are screenplays for plays and dialogues that are performed. When students are working on plays, it is critical that they treat the script as if it were a real acting assignment. In other words, we need to assist them in reading through the scripts as if we were theatre directors, calling attention to appropriate stress, intonation, and speed throughout the process. In other words, the lines they speak will have genuine significance. Teacher ensures that acting out is both a learning and a language-producing activity by providing students with practice in these areas before they present their final performances.

\section{Acting Out Dialogues}

When choosing who should come out to the front of the class, teachers should be careful not to choose the shyest students first. They need to work to create the right kind of supportive atmosphere in that class. They need to give students time rehearse their dialogues before they are asked to perform them. If they can give students time to work on their dialogues, they will gain much more from the whole experience.

\section{Communication Games}

There are many communication games, all of which aim to get students talking as quickly and fluently as possible. Two particular categories are worth mentioning here. They are: (1) Information-gap games: Many games depend on an information gap games one student has to talk to a partner in order to solve a puzzle, draw a picture (describe and draw), put things in the right order (describe and arrange) or find similarities and differences between pictures. (2) Television and radio games: When imported into the classroom, games from radio and TV often provide good fluency activities, as the following example demonstrate. 'In Twenty questions' the chairperson thinks of an object and tells a team that object is either animal, vegetable or mineral-or a combination of two or three of these. The team has to find out what the object is asking only yes/no questions, such as Can you use it in kitchen? Or Is it bigger than person? They get points if they guess the answer in 20 questions or fewer (Harmer,2007). 


\section{Oral Presentation}

In the words of Tompkins and Hoskisson (1991), "Oral Presentation is an activity or method that engages students in learning how to prepare and present their language orally." As a result, learning how to prepare and deliver an oral report or presentation is a vital language skill for students who grow to be afraid of speaking in front of a group rather than developing confidence in their oral language talents. The process of having students present or describe their spokes, whether chosen by the teacher or chosen by themselves, is extremely necessary and appropriate for the level of Junior High School kids in order to train them in how to use language effectively. This is also reinforced by O'Malley and Pierce (1999), who state that an Oral Report/Presentation is not delivered by reading aloud but rather by referring to notes or cue cards that the student has made. Students must prepare for an oral presentation, which can be customized to accommodate students of all levels of ability and competency. Oral presentations have several advantages, as O'Malley and Pierce (1999) outline in their list of advantages of oral presentations. They are as follows: (1) it is conducted in a casual and relaxed environment; (2) it is conducted over a number of days with each student; (3) it incorporates observation or an oral presentation; and (4) it is conducted in a group setting.

\section{The teaching of Speaking at SMPN 35 Surabaya}

The basic standards that the students have to reach are such as: Listening, Speaking, Reading, and Writing (Depdiknas, 2006). The speaking skills has not been emphasized much in the teaching of English at the Junior High School level. In the teaching of speaking, the teacher mostly emphasizes his/her teaching product of speaking. It means that the teacher occasionally practices the teaching of speaking, started by only explaining the topic the students are going to speak about while the students listen to the explanation. No model is provided to the students as the example. The students then are asked to write and read a short dialogue or composition in certain time allowed without practice to speak in oral or to product what they have learned before.

\section{Teaching Speaking through Oral Presentation}

According to Brown (2004), oral reports are a type of oral presentation. He went on to explain that it was not ordinary in academic and professional settings to be asked to deliver a report, a paper, a marketing plan, a sales proposal, a design for a new product, 
or a method. Furthermore, he stated that "a overview of oral evaluation approaches would be insufficient if it did not include some examination of prolonged speaking tasks." When conducting an assessment, it is necessary to follow the rules of effective assessment: (a) describe the criterion, (b) create appropriate tasks, (c) elicit optimal output, and (d) construct practical, accurate scoring processes. The most difficult aspect of the game is scoring. The use of a checklist or grid for scoring or evaluation is typical when presenting information. Although holistic scores are attractive to utilize because of their seeming practicality, they may mask the variety of performance across several subcategories, particularly the two key components of content and delivery, which are both very variable.

\section{RESEARCH METHODS}

\section{Research Design}

The researcher employed a qualitative technique in conjunction with a Classroom Action Research design for this investigation. Theoretically, according to Latief (2004, p. 99), "Classroom Action Research (CAR) for English Learning aims at developing learning-teaching strategies that complement learners' styles and strategies in learning English." CAR may be performed in several cycles, each of which is repeated in the following cycle if the result is not satisfactory yet with the better amended lesson plan. CAR may be performed in several cycles, each of which is repeated in the following cycle if the result is not satisfactory yet. In light of the goal of Classroom Action Research, which is to improve the quality of teaching and learning, the researcher sought to apply this design to improve the speaking skills of ninth-grade students at SMPN 35 Surabaya through oral presentation. As the researcher in this study, he or she serves as the designer, observer, practitioner, and rater of the Classroom Action Research implementation, and he or she collaborated with the collaborator who aided him or her in ensuring the validity of the results.

The definition of action research given by Mills (2006) is any systemic inquiry conducted by teachers, researchers, principals, school counselors, or other stakeholders in the teaching and learning environment, who come together to share information about the ways in which their particular school operates, the ways in which they teach, and the levels of achievement of their students. In order to gain insight, create reflective practice, 
bring about good changes in the school environment, and improve/increase students' outcomes as well as the quality of life for all engaged, this information is gathered. Using the design of Kemmis and McTaggart (in Kasbollah and Sukaryana, 2001), this study was conducted as classroom action research, in which each cycle consists of four steps: planning of action, implementing action, observing and evaluating the action, and finally analysis and reflection. Commenced with reconnaissance (preliminary investigation), followed by analysis and identification of the problem, as depicted in the image below, followed by the four key processes.

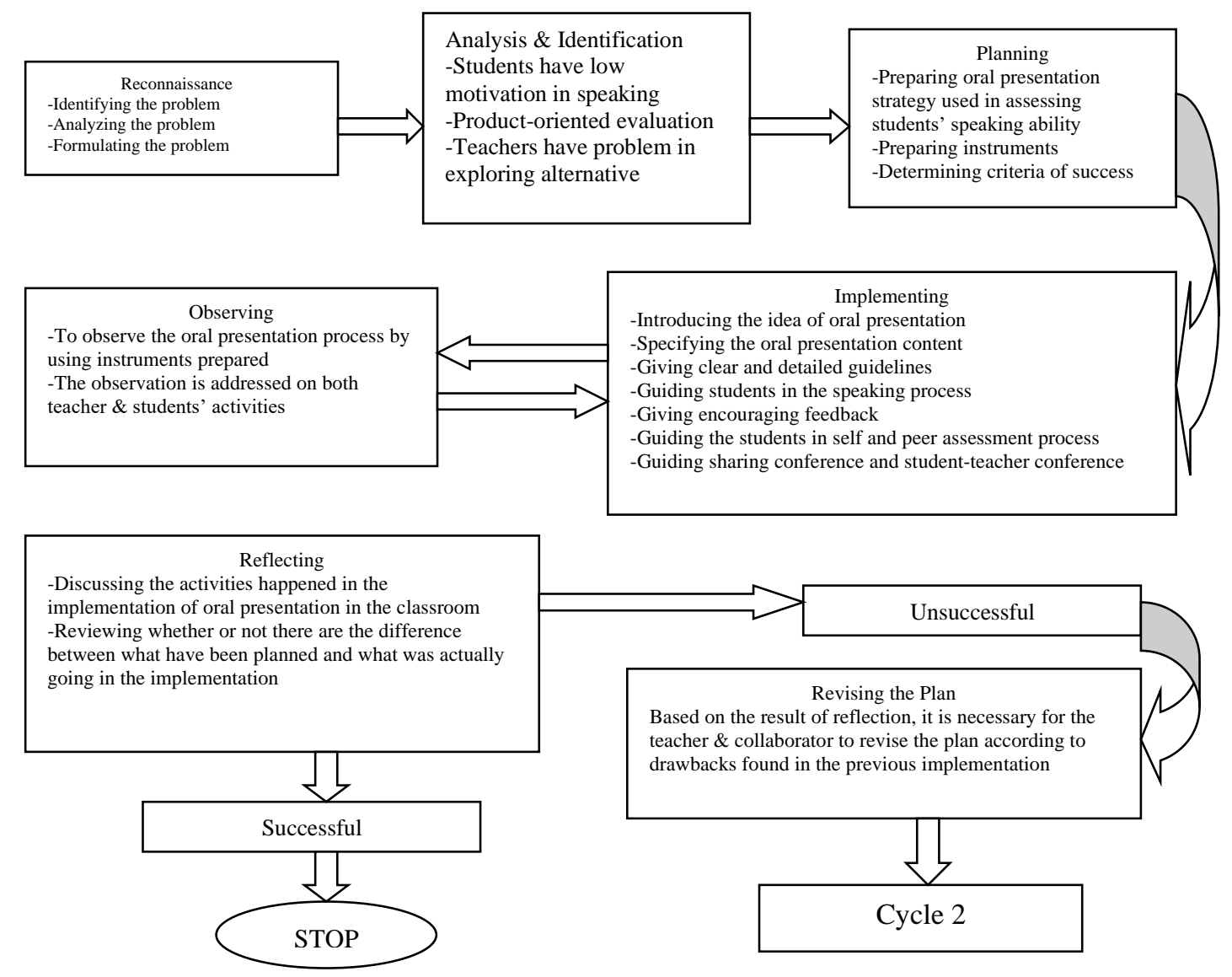

Figure 1. The Classroom Action Research Procedure

\section{Research Setting and Subjects}

This action research was conducted at SMPN 35 Surabaya. There are three English teachers, the researcher is one of the English teachers at this school. The subject of this study were the students of the first semester of 2020/2021 academic year. There are three parallel classes of the seventh-grade students in this school. Therefore, the researcher took one them for the study. The selected classes were the 9-A class that 
consist of 41 students, the researcher took all them as the subject of the study. The researcher chose this school and the ninth-grade students as the subjects of his study for the following reasons. First, the researcher would like to make a new innovation in developing the teaching and learning process, especially in teaching speaking skills. Second, the English teachers at this school still had a problem to explore an appropriate strategy to improve the students' speaking skill. Third, the students still found difficulties in speaking, since the teacher focused their teaching mostly on grammatical exercises and the product of speaking. Fourth, the classroom activities did provide students with sufficient speaking practice. Even though the teaching of English was very limited. Fifth, the oral presentation had not been applied at this school. Finally, the English teachers said that they knew a little about oral presentation strategy and interested to try out how oral presentation strategy works in the classroom.

\section{Research Procedure}

In this study the researcher was designer of the action, the observed and the rater of the students' speaking performance. Meanwhile, the collaborator was the assistant and the rater of the students' speaking test in order to keep the reliability of the test. The action was administered for two cycles. Each cycle consisted of two meetings. After observing and reflecting the action, the researcher evaluated whether or not the action had fulfilled the criteria of success. If the action did not meet the criteria of success, the action would be continued to the next cycle. On the other hand, if the action had fulfilled of the criteria of success, the action would be stopped. In this study, the implementation of the action, was conducted during the teaching-learning process in the first semester of academic year 2020/2021. The description of the steps in implementing the Oral Presentation or Oral Report Work activity was presented as follows:

Table 1. The implementation of Oral Presentation in "Problemsolving and Decision Making" activity

\begin{tabular}{|l|l|l|}
\hline No & Stages & Activities in class \\
\hline 1 & Pre-activity & $\begin{array}{l}\text { 1. Warming-up } \\
\text {-greeting and checking students' attendance list } \\
\text {-giving brainstorming activity } \\
\text {-introducing the oral Presentation or Oral Report Work activity. } \\
\text { Telling the purpose of the activity } \\
\text {-giving detailed instructions on how to do the activity. }\end{array}$ \\
\hline 2 & Main-activity & $\begin{array}{l}\text { 2. Implementation of "Oral Presentation or Oral Report. Making } \\
\text { activity: } \\
\text {-dividing the class into group of five }\end{array}$ \\
\hline
\end{tabular}




\begin{tabular}{|c|c|c|}
\hline & & $\begin{array}{l}\text {-giving a problem to solve and asking them to discuss it in their } \\
\text { group } \\
\text {-giving chance to each group to report the result of their groups } \\
\text { give responses }\end{array}$ \\
\hline 3 & Post-activity & $\begin{array}{l}\text { 3. Closing } \\
\text {-evaluating the students' performance by giving comments and } \\
\text { correction on students' mistakes related to pronunciation, } \\
\text { grammar and vocabulary } \\
\text {-motivating the students to be more confident to speak } \\
\text {-closing the meeting }\end{array}$ \\
\hline
\end{tabular}

\section{Instrument of Research}

\section{Observation}

In this study, the researcher did the observation during the implementation of Oral Presentation or Oral Report activities. In order to get accurate and reliable data, the researcher made use of some instruments, such as observation format, field note, and test. The observation format was used for gathering data on the students' oral proficiency which covers pronunciation, grammar, vocabulary, fluency, and comprehensibility. The observation format included the description of the students' oral proficiency and the score which range from $1-10$. The data obtained from the observation activities were taken into account to measure the improvement or progress of the students' speaking ability.

\section{Test}

Test was categorized as oral test of speaking ability. It was used to gain the score of students' speaking ability. During the students' presenting or action, the researcher observed how the students used their English based on the given tasks and administrated it in the form of score. In this study, the teacher used an analytical rating score. It contains the analytic score that the ability was observed separately under the language components: pronunciation, grammar, vocabulary, fluency, and comprehensibility in a 110 scale. The ability was observed or evaluated by two raters namely the researcher herself and the collaborator to keep the reliability of the test result. There were two kinds of test: (1) Preliminary test, which was to get the general description about the students' speaking ability before the implementation of oral presentation or oral report work activities. (2) On going test, which was used to know the progress or improvement of the students' speaking ability after the implementation of the action. 
Pronunciation

Table 2. Description of Oral proficiency by Hughes (2003:131)

\begin{tabular}{|l|l|l|}
\hline No & \multicolumn{1}{|c|}{ Proficiency Description } & \multicolumn{1}{|c|}{ Scale of Score } \\
\hline 1. & $\begin{array}{l}\text { Pronunciation frequently unintelligible } \\
\text { Frequent gross errors and very heavy accent. }\end{array}$ & $1.0-4.5$ \\
3. & $\begin{array}{l}\text { Make understanding difficult, require frequent repetition } \\
\text { "Foreign accent" requires concentrated listening, and } \\
\text { mispronunciation lead to occasional misunderstanding }\end{array}$ & $5.6-6.5$ \\
4. & $\begin{array}{l}\text { Marked "Foreign accent" and occasional mispronunciation } \\
\text { which do not interfere with understanding. }\end{array}$ & $6.6-7.5$ \\
5. & $\begin{array}{l}\text { No conspicuous mispronunciations, but would not be taken for } \\
\text { a native speaker }\end{array}$ & $7.6-8.5$ \\
6. & Native pronunciation, with no trace of "Foreign accent" & $8.6-10.0$ \\
\hline
\end{tabular}

\section{RESEARCH FINDINGS AND DISCUSSION}

\section{Cycle 1}

This section began with cycle 1 . After being implemented, it was observed and evaluated whether it would be continued to the next cycle or not. There were two meetings in this cycle. The planning of the action started by deciding the type of tasks or assignments, deciding the topics of the activity, and designing the lesson plan. The teacher evaluated how the activity was going on and commented on the group performances by doing some corrections on the students' mistakes mainly on pronunciation, grammar, vocabulary, and comprehensibility, based on their findings during the observation process. Finally, the teacher closed the lesson and ready to have the greeting from the students, and it was followed by saying 'goodbye' and 'see you next meeting'. The result of the students' speaking ability in this cycle is presented below.

Table 3. The Score of the speaking skill from the researcher and the collaborator in cycle 1

\begin{tabular}{|c|c|c|c|c|c|c|c|c|c|c|c|c|c|c|}
\hline \multirow{2}{*}{ Name } & \multicolumn{5}{|c|}{ Researcher } & \multirow{2}{*}{ Total } & \multirow{2}{*}{ Avg } & \multicolumn{5}{|c|}{ Collaborator } & \multirow{2}{*}{ Total } & \multirow{2}{*}{ Avg } \\
\hline & Pro. & Gra. & Voc. & Flue. & Com & & & Pro & Gra & Voc & Flue. & Com & & \\
\hline S1 & 5.0 & 5.0 & 6.0 & 6.0 & 7.0 & 29.1 & 5.80 & 5.5 & 5.4 & 6.2 & 6.3 & 6.2 & 29.7 & 5.94 \\
\hline $\mathrm{S} 2$ & 6.5 & 6.6 & 6.4 & 6.7 & 6.8 & 33.0 & 6.60 & 6.6 & 6.7 & 6.5 & 6.8 & 6.9 & 33.5 & 6.70 \\
\hline S4 & 8.0 & 8.5 & 8.0 & 7.5 & 7.8 & 39.8 & 7.96 & 8.2 & 8.6 & 8.2 & 7.8 & 7.9 & 40.7 & 8.14 \\
\hline S5 & 6.8 & 8.0 & 8.0 & 7.4 & 7.8 & 38.0 & 7.60 & 6.9 & 8.2 & 8.2 & 7.4 & 7.6 & 38.3 & 7.66 \\
\hline S6 & 5.0 & 5.0 & 6.0 & 6.0 & 7.0 & 29.0 & 5.80 & 5.0 & 5.0 & 6.0 & 6.0 & 7.0 & 29.0 & 5.80 \\
\hline S8 & 6.4 & 6.5 & 6.6 & 6.8 & 7.0 & 33.3 & 6.66 & 6.4 & 6.5 & 6.6 & 6.8 & 7.0 & 33.3 & 6.66 \\
\hline S9 & 6.8 & 8.0 & 8.0 & 7.4 & 7.8 & 38.0 & 7.60 & 6.8 & 8.0 & 8.0 & 7.4 & 7.8 & 38.0 & 7.60 \\
\hline $\mathrm{S} 10$ & 5.8 & 5.9 & 6.0 & 6.5 & 6.6 & 30.8 & 6.16 & 5.8 & 5.8 & 7.0 & 6.4 & 6.5 & 31.5 & 6.30 \\
\hline S11 & 6.8 & 8.0 & 8.0 & 7.4 & 7.8 & 38.0 & 7.60 & 6.9 & 8.0 & 8.0 & 7.5 & 6.7 & 37.1 & 7.42 \\
\hline S12 & 6.4 & 6.5 & 6.6 & 6.8 & 7.0 & 33.3 & 6.66 & 6.5 & 6.5 & 6.5 & 6.7 & 7.1 & 33.3 & 6.66 \\
\hline S13 & 6.5 & 6.6 & 6.4 & $\begin{array}{l}6.7 \\
\end{array}$ & 6.8 & 33.0 & 6.60 & 6.6 & 6.6 & 6.4 & 6.7 & 6.8 & 33.1 & 6.62 \\
\hline
\end{tabular}




\begin{tabular}{|l|l|l|l|l|l|l|l|l|l|l|l|l|l|l|}
\hline S16 & 5.0 & 5.0 & 6.0 & 6.0 & 7.0 & 29.0 & 5.80 & 6.0 & 6.0 & 6.0 & 6.0 & 7.0 & 31.0 & 6.20 \\
\hline S17 & 6.4 & 6.5 & 6.6 & 6.8 & 7.0 & 33.3 & 6.66 & 6.5 & 6.5 & 6.5 & 6.7 & 7.2 & 33.4 & 6.68 \\
\hline S18 & 7.4 & 7.6 & 7.8 & 7.5 & 7.8 & 38.1 & 7.62 & 7.5 & 7.5 & 7.6 & 7.4 & 7.7 & 37.7 & 7.54 \\
\hline S19 & 6.8 & 8.0 & 8.0 & 7.4 & 7.8 & 38.0 & 7.60 & 6.7 & 8.2 & 8.0 & 7.3 & 7.6 & 37.8 & 7.56 \\
\hline S20 & 6.4 & 6.5 & 6.6 & 6.8 & 7.0 & 33.3 & 6.66 & 6.4 & 6.4 & 6.5 & 6.6 & 7.0 & 32.9 & 6.58 \\
\hline Total & 120.2 & 137.3 & 140.8 & 138.1 & 146.4 & 691.9 & 138.36 & 131.9 & 139.0 & 142.2 & 134.3 & 144.5 & 697.0 & 139.37 \\
\hline Mean & 6.46 & 6.86 & 7.04 & 6.09 & 7.32 & 34.595 & 6.92 & 6.59 & 6.95 & 7.11 & 6.96 & 7.22 & 34.85 & 6.97 \\
\hline
\end{tabular}

$\mathrm{X} 1$ = Researcher's scoring

$\mathrm{X} 2$ = Collaborator's scoring

So, $\mathrm{X} 1=138.36: 20=6.918$

$$
\begin{aligned}
& =6.92 \\
X 2=139.37: 20 & =6.968 \\
& =6.97 \\
X=(6.92+6.97) & : 2=6.945=6.95
\end{aligned}
$$

The data shows that two indicators of success were fulfilled: there were 9 out of 20 students or about $46 \%$ students who were actively involved in the speaking activity. It means that there was an increase in the number of students who actively participated in the speaking activity, and the students seemed more confident and had less anxiety in using the target language orally. However, another criterion was not fulfilled, that is, the mean score could only 6.20, whereas the target score was 7.0 (the minimum standard) because 7.0 is the minimum standard score of school for the seventh- grade students at the SMPN 35 Surabaya. Finally, the researcher concluded that the implementation of oral presentation activities in improving the students' speaking ability in cycle 1 was not satisfying yet. Thus, the action in cycle 1 should be revised and then continued to the next cycle that is cycle 2 .

\section{Cycle 2}

There were two meetings in the cycle. Considering the result of the implementation of the action in cycle 1 , the researcher has made some revision on the procedure of the oral presentation or oral report implementation. In this cycle, the researcher and the collaborator were directly involved in guiding the students during the activity. It was done to minimize the students' problems or difficulties, especially on pronunciation, and vocabulary. The teacher divided the class into small groups with five students for each, consisting of one leader and four members. The teacher gave them a topic to discuss and to prepare. It was about "Some Professions". With the topic, the students were supposed to get some ways out to finish the problem. The way out should be supported by their presentation or reporting in front of the class. during this activity, 
the teacher should move around the class to ensure if the students needed her help. The students were supposed to finish their work of preparation in 20 minutes. When all groups were ready, they were given chance to present or to report their ideas or opinions to the class and the other groups should listen and gave their responses. During this activity, both the researcher and the collaborator were doing their observation and field note. It was done for about 40 minutes. In this section, the researcher presented and reported the data, instruments, and techniques used for collecting data, and sources of data. The data obtained were quantified and presented on the table below:

Table 3. The Score of the students' speaking ability from the researcher and the collaborator in cycle 2

\begin{tabular}{|c|c|c|c|c|c|c|c|c|c|c|c|c|c|c|}
\hline \multirow{2}{*}{ Name } & \multicolumn{5}{|c|}{ Researcher } & \multirow{2}{*}{ Total } & \multirow{2}{*}{ Avg } & \multicolumn{5}{|c|}{ Collaborator } & \multirow{2}{*}{ Total } & \multirow{2}{*}{ Avg } \\
\hline & Pro. & Gra. & Voc. & Flue. & Com & & & Pro & Gra & Voc & Flue. & Com & & \\
\hline S1 & 6.4 & 7.4 & 7.5 & 7.6 & 7.8 & 36.7 & 7.34 & 6.3 & 7.3 & 7.4 & 7.4 & 7.6 & 36.0 & 7.20 \\
\hline S2 & 6.7 & 6.8 & 7.2 & 7.2 & 7.1 & 35.0 & 7.00 & 6.8 & 6.7 & 7.1 & 7.1 & 7.2 & 35.0 & 7.00 \\
\hline S3 & 7.6 & 7.7 & 7.8 & 7.8 & 7.8 & 38.7 & 7.74 & 7.6 & 7.6 & 7.7 & 7.7 & 7.6 & 38.2 & 7.64 \\
\hline S4 & 8.3 & 8.7 & 8.3 & 8.5 & 8.3 & 42.1 & 8.42 & 8.2 & 8.6 & 8.4 & 8.4 & 8.2 & 41.8 & 8.36 \\
\hline S5 & 7.1 & 8.3 & 8.4 & 7.6 & 7.7 & 39.1 & 7.82 & 7.1 & 8.2 & 8.3 & 7.6 & 7.6 & 38.8 & 7.76 \\
\hline S6 & 6.2 & 6.4 & 6.5 & 6.4 & 7.2 & 32.7 & 6.54 & 6.3 & 6.4 & 6.4 & 6.6 & 7.2 & 32.9 & 6.62 \\
\hline S7 & 6.1 & 6.2 & 6.4 & 6.4 & 7.1 & 32.2 & 6.44 & 6.1 & 6.3 & 6.3 & 6.4 & 7.1 & 32.2 & 6.44 \\
\hline S8 & 6.5 & 6.6 & 6.8 & 7.0 & 7.2 & 34.1 & 6.82 & 6.5 & 6.6 & 6.8 & 7.1 & 7.2 & 34.2 & 6.84 \\
\hline S9 & 6.9 & 8.2 & 8.4 & 7.8 & 7.9 & 39.2 & 7.84 & 6.9 & 8.2 & 8.3 & 7.8 & 7.9 & 39.1 & 7.82 \\
\hline S10 & 7.1 & 6.4 & 7.4 & 7.4 & 7.6 & 35.9 & 7.18 & 7.1 & 6.5 & 7.3 & 7.3 & 7.4 & 35.6 & 7.12 \\
\hline S11 & 7.2 & 8.0 & 8.0 & 7.5 & 6.8 & 37.5 & 7.50 & 7.2 & 8.0 & 8.1 & 7.6 & 6.9 & 38.2 & 7.64 \\
\hline $\mathrm{S} 12$ & 7.2 & 7.1 & 7.4 & 7.6 & 7.8 & 37.1 & 7.42 & 7.3 & 7.2 & 7.3 & 7.5 & 7.7 & 37.0 & 7.40 \\
\hline S13 & 6.8 & 6.8 & 6.6 & 6.8 & 6.9 & 33.9 & 6.78 & 6.9 & 6.8 & 6.7 & 6.9 & 7.1 & 34.4 & 6.88 \\
\hline $\mathrm{S} 14$ & 8.5 & 8.5 & 8.2 & 8.5 & 8.2 & 41.9 & 8.38 & 8.4 & 8.4 & 8.2 & 7.4 & 7.7 & 42.1 & 8.42 \\
\hline S15 & 6.7 & 8.0 & 8.0 & 7.4 & 7.7 & 37.8 & 7.56 & 6.8 & 8.0 & 8.0 & 7.4 & 7.7 & 37.9 & 7.58 \\
\hline S16 & 6.4 & 7.8 & 7.8 & 6.8 & 7.2 & 36.6 & 7.32 & 6.4 & 7.8 & 7.8 & 6.8 & 7.8 & 36.6 & 7.32 \\
\hline S17 & 6.6 & 7.9 & 7.9 & 7.4 & 7.5 & 37.3 & 7.46 & 6.6 & 7.7 & 7.9 & 7.5 & 7.5 & 37.3 & 7.46 \\
\hline S18 & 7.6 & 7.6 & 7.6 & 7.5 & 7.8 & 38.1 & 7.62 & 7.7 & 7.6 & 7.6 & 7.5 & 7.8 & 38.2 & 7.64 \\
\hline S19 & 6.7 & 8.2 & 8.0 & 7.3 & 7.6 & 37.8 & 7.56 & 6.7 & 8.1 & 8.0 & 7.2 & 7.5 & 37.5 & 7.50 \\
\hline S20 & 6.8 & 6.9 & 6.8 & 7.5 & 7.2 & 35.2 & 7.04 & 6.8 & 6.9 & 6.8 & 7.4 & 7.3 & 35.2 & 7.04 \\
\hline Total & 139.4 & 149.5 & 151.0 & 148.0 & 150.4 & 738.9 & 147.71 & 139.4 & 139.7 & 148.9 & 150.4 & 146.6 & 738.2 & 140.6 \\
\hline Mean & 6.97 & 7.47 & 7.55 & 7.04 & 7.52 & 36.94 & 7.385 & 69.7 & 6.985 & 7.44 & 7.52 & 7.33 & 36.91 & 7.03 \\
\hline
\end{tabular}

$\mathrm{X}_{1}=$ Researcher's scoring

$\mathrm{X}_{2}=$ Collaborator's scoring

So, $\mathrm{X}_{1}=147.71: 20=7.39$

$$
\begin{aligned}
& X_{2}=140.6: 20=7.03 \\
& X=(7.39+7.03): 2=7.21
\end{aligned}
$$

Based on the data obtained, the researcher got some results dealing with the implementation of Oral Presentation or Oral Report Work activities applied in cycle 2. Firstly, the researcher found that the students seemed more confident and enthusiasm to express their opinions or ideas through oral presentation or oral report orally. The students felt more enjoyable when they were working in presenting or in giving report and it was 
very helpful for the shy students. Secondly, being in presenting or reporting, the students felt less anxious to make mistakes they made would be helpful corrected by the other students. So, such condition was able to create a stress-free atmosphere within the students and a natural situation in which the students felt safer to use their English. This situation is very beneficial to improve their grammar, vocabulary, comprehensibility, and fluency. Finally, the researcher concluded that the implementation of oral presentation activities in Cycle 2 brought a success. Two indicators of success criteria were fulfilled: there was an increase in the number of students who were actively involved in speaking ability. The number of the active students exceed to the passing grade or target grade, from $50 \%$ in cycle 1 to $70 \%-75 \%$ in cycle 2 or there were $16-18$ out of 20 students who actively participated in the speaking activity. Thus, the action could be stopped.

According to the results in the two cycles, the researcher discusses some points related to the successful implementation of oral presentation technique in teaching speaking aimed at improving the students' speaking ability. The complete discussions are as follows: Firstly, it was proved that oral presentation technique could improve the students' speaking ability due to some facts. The fact showed that before this technique was implemented, the result of the preliminary study on students' speaking ability was low. The data showed that the mean score reached only 6.19 (the stated passing score was 7.0). After the two cycles carried out or conducted, some improvements could be obviously seen. The mean score in cycle 1 showed on increase to 6.92. Although the result does not show a satisfying score yet, it can be said that oral presentation could improve the students' speaking ability. After the action in cycle 1 was revised, the action in cycle 2 was applied, the data showed a successful result. The mean score of the students' speaking ability could reach the passing grade or score that is 7.21 . Thus, the result proves that oral presentation could improve the students speaking ability.

Secondly, through oral presentation the teacher is able to create a good and natural class atmosphere. Such atmosphere is very beneficial for students to have more initiatives to express their opinions or ideas by using English. This statement was supported by Klippel (1984:7) saying that the concussive atmosphere of the class played an important role in speaking class. By using oral presentation technique, the students are facing real and natural situations in which they are able to interact with other people, friends without too much inhibition and anxiety. It is proved by the data showing that there were on 5 
students who were actively before the implementation of this technique. Gradually, the data showed an increasing in the number of the students who were active in the speaking activity. There were 9 students in first cycle and 14 students in the second cycle. Therefore, it can be concluded that oral presentation technique is very applicable to teach speaking.

Another advantage of this technique is that oral presentation is able to create a cooperative learning situation among students. As stated by Oxford (1999:70) that because languages are all aspects is a social act or speech act, cooperating with other people is essential. Besides, while the students were doing a group activity, the researcher noticed that a take and give activity occurred. Such situation is very helpful for students who are shy or less confidence so that it allows them to interact with other friends or their friends. Furthermore, oral presentation activities provide students ample opportunities to practice public speaking by using their English orally in more natural and interactive situations. Since the students have more chances to practice their English, it is quite effective for them to improve their grammar, vocabulary, pronunciation, fluency, and comprehensibility. Finally, it is hoped that through oral presentation activities, English language teacher are able to anticipate the biggest problems they have, that is finding shy students, silent students, passive students, and unmotivated students in teaching and learning English, especially when they are in their speaking class.

\section{CONCLUSION}

By knowing the facts that the speaking ability of the ninth-grade students at SMPN 35 Surabaya was very low, which was proved by the preliminary study conducted, the researcher was highly motivated to held or conduct research to improve their speaking ability through Oral Presentation or Oral Reports Work technique or strategy in teaching speaking. Based on the data obtained and the reflection during the action in cycle 1 , the researcher concluded that although the result showed there was an improvement in the students' speaking ability, the action in cycle 1 had some weaknesses so that it had to be revised and continued to the next cycle, that was cycle 2 . Based on the obtained, the result of the action in cycle 2 showed a satisfying result. Where the mean score of the students' speaking ability could reach 7.21. It means that the score could fulfill the passing score or stated criteria of success that is 7.0. Where there were 16 students out of 20 students 
who actively participated in the speaking activity that is in presenting or reporting their topics assignments given by their teacher or chosen by themselves and for completing information. Considering the result, the researcher decided to end or to stop the action up to the second cycle.

\section{REFERENCES}

Brown, D. H. (2004). Language Assessment: Principle and Classroom Practices. New York: Pearson Education Inc.

Harmer, J. (2007). How to Teach English: New Edition. England : Pearson Education Ltd. Longman.

Kemmis, S., \& McTaggart, R. (1982). The Action Research Planner . Geelong, Victoria: Deakin University Press.

Latief, A. M. (2004). Pembelajaran, Penilaian dan Penelitian Bahasa Inggris. Malang: Universitas Negeri Malang.

Mills, G. E. (2006). Action Research: A Guide for the Teacher Research . New Jersey: Prentice Hall Inc.

Nunan, D. (1991). Language Teaching Methodology: A Textbook for Teachers. United Kingdom: Prenties Hall.

O’ Malley, J. M., \& Pierce, V. L. (1996). Authentic Assessment For English Language Learners; Practical Approaches for Teacher. New York: AbdisomWesley Publishing Company, Inc.

Richards, J. C., \& Renandya, W. A. (2002). Methodology in Language Teaching: An Anthology of Current Practice . Cambridge : Cambridge University Press.

Tompkins, E. G., \& Hoskisson, K. (1991). Language Arts; Content and Teaching Strategies. New York:: Macmi Publishing Company. 